\title{
ULTRATHIN POLY(3-HYDROXYBUTYRATE) FIBERS: STRUCTURE AND DYNAMIC CHARACTERISTICS
}

\author{
Svetlana Gennadyevna Karpova \\ Senior Researcher, \\ Institute of Biochemical Physics named after N. M. Emanuel, RAS \\ ibcp@sky.chph.ras.ru \\ Kosygina St., 4, 119334 Moscow, Russian Federation
}

Aleksey Leonidovich Iordanskiy

Doctor of Chemical Sciences, Professor, Head of Laboratory of Diffusion Phenomena in Polymer Systems, N. N. Semenov Institute of Chemical Physics, RAS aolkhov72@yandex.ru

Kosygina St., 4, 119991 Moscow, Russian Federation

Mikhail Viktorovich Motyakin

Doctor of Chemical Sciences, Professor, N. N. Semenov Institute of Chemical Physics, RAS icp@chph.ras.ru

Kosygina St., 4, 119991 Moscow, Russian Federation

Anatoliy Aleksandrovich Olkhov

Candidate of Technical Sciences, Associate Professor, Senior Researcher, Laboratory of Prospective Compositional Materials and Technologies, Russian University of Economics named after G. V. Plekhanov aolkhov72@yandex.ru Stremyanny Pass., 36, 117997 Moscow, Russian Federation

\section{Sergey Modestovich Lomakin}

Candidate of Chemical Sciences, Head of Laboratory of Chemical Firmness of Polymers, Institute of Biochemical Physics named after N. M. Emanuel, RAS ibcp@sky.chph.ras.ru Kosygina St., 4, 119334 Moscow, Russian Federation

\section{Aleksandr Aleksandrovich Berlin}

Doctor of Chemical Sciences, Professor, Academician of RAS, Director of N. N. Semenov Institute of Chemical Physics, RAS berlin@chph.ras.ru Kosygina St., 4, 119991 Moscow, Russian Federation

Abstract. Structural and dynamic analysis based on combined thermophysical and molecular-mobility measurements via spin-probe ESR spectroscopy has been applied to films 
and fibrous matrixes based on poly(3-hydroxybutyrate). The dynamic behaviors of partially crystalline samples during deformation under conditions of electrospinning and cold rolling have been compared. The comparative results of the complex investigation of films and ultrathin fibers in the poly(3-hydro-xybutyrate) matrix have shown that the electromechanical action leads to additional crystallization of the crystalline regions, spherulites, and lamellas in the polymer. The changes in the crystalline phase of the polymer are accompanied by an increase in the packing density of macromolecules in the intercrystalline space. With the use of the spin-probe ESR method, the effect of water and the oxidant ozone on the morphology of the amorphous phase of poly(3-hydroxybutyrate) ultrathin fibers has been determined. The measurements of the dynamics of spin-probe rotation in samples before and after cold rolling have shown that the additional orientation of poly(3-hydroxybutyrate) spherulites in a mechanical field results in stabilization of amorphous regions more resistant to the aggressive effects of ozone.

Key words: poly(3-hydroxybutyrate), structural and dynamic analysis, films, ultrathin fibers, polymer.

Ultrathin fibrillar structures(fibers, fibrils, nets, and porous fibrous matrixes) are of great interest as advanced functional materials with specific properties owing to the high surface-volume ratio for an individual filament, the capacity for surface modification, and the controllable mechanical characteristics and diffusion transport features [13]. At present, ultrathin fibers and the related products have found wide application in biomedicine, cell engineering, separation and filtration processes, the production of reinforced composites, electronics, analytics, sensor diagnostics, and a number of other innovative areas [4-6].

The formation of fibers and filaments of submicron and nano diameters via conventional spinning technologies is accompanied by significant difficulties [7].

At present, the alternative to ultrathin-fiber formation is an original technology that is based on electrospinning and allows the production of fibers and related unwoven materials. In regards to the equipment, electrospinning is a technologically simple, but multiparameter process of formation of microand nanofibers $10 \mathrm{~nm}-10 \mu \mathrm{m}$ in diameter [8]. The electrospinning process is based on the combined action of mechanical and electrostatic forces applied to a polymer solution or a melt oriented in an electric field [9]; thus, some parameters such as the potential at the electrodes, the distance between the electrodes, conductivity, and the density and viscosity of the spinning polymer system-affect the morphology, surface properties, functionality, porosity, and geometry of fibers [10].
In previous works $[11 ; 12 ; 20]$, for the examples of the natural polyester poly(3-hydroxybutyrate) (PHB) and a number of its compositions with other polymers, the physico-+chemical, dynamic, and transport characteristics of macroscopic biodegradable matrixes and microparticles of PHB that are prospective for prolonged and controlled drug delivery were studied [13].

The high biocompatibility, controlled biodegradation, and satisfactory mechanical characteristics make it possible to consider this polymer one of the most promising for biomedical use. PHB is not only used therapeutically but also widely applied for the development of bone implants, nerve fiber connections, matrixes for cell and tissue cultivation, and filters and ultrafiltration membranes as well as for the design of artificial heart ele-ments and vascular prostheses [14; 20].

At present, there is a number of methods for obtaining oriented polymer structures: for example, blow molding, hot molding, compression stretching, and die extrusion of fibers [15]. These methods are widely used in manufacturing; however, sometimes they are accompanied by an undesirable effect, such as the formation of microand macrocavitation defects, which deteriorate the diffusion and strength characteristics of fibers and films [16]. Fibers prepared via electrospinning are less prone to defect formation.

Moreover, to improve the orientation of ultrathin fibers, the cold rolling technique (related to compression methods), which minimizes the formation of defect voids in the fibrous matrix, has been employed [17]. In spite of some 
limitations, the above method has a low energy consumption and, hence, remains among most economical processes of polymer material production.

The transfer from film and matrix systems to fibers and related unwoven materials is accompanied by significant changes in their physico-chemical and transport characteristics, a circumstance that is related to the space limitations arising in ultrathin fibers and affecting the dynamics and set of macromolecular conformations [18].

In this study, some structural and dynamic characteristics of PHB matrixes formed from ultrathin fibers were compared at the molecular level to reveal features of the diffusion mobility and degradation processes occurring during space limitations. With the use of spin-probe ESR spectroscopy, the influence of water and the oxidant ozone on the structure of the fibrous PHB matrix was demonstrated, a circumstance that made it possible to estimate the changes in the segmental mobility of macromolecules at the early stages of their interaction with aggressive media.

\section{Experimental}

For film preparation, the natural biodegradable polymer PHB 16F (Bio-mer ${ }^{\circledR}$, Germany), obtained via microbiological synthesis, was used. The pristine polymer is a white finely dispersed powder with a particle size from 5 to $20 \mu \mathrm{m}$. The viscosity-average molecular mass of the polymer was $M=2.06 \times 10^{5}$, the density was $\rho=1.248 \mathrm{~g} / \mathrm{cm}^{3}$, the melting temperature was $T_{\mathrm{m}}=177^{\circ} \mathrm{C}$, and the crystallinity was $65 \%$. Ultrathin fibers of PHB were prepared via electrospinning [19]. The fibers were formed from 5 and $7 \%$ PHB solutions in chloroform. The process of spinning ultrathin fibers of PHB was described in more detail in [21]. The physical modification of the structure of PHB-based unwoven materials was performed via rolling between two metal rollers rotating at a rate of $30 \mathrm{rpm}$ and providing a pressure of $20 \mathrm{MPa}$ at $22 \pm 1{ }^{\circ} \mathrm{C}$ (so called "cold" rolling [22]). As a result of the rolling, the effective thickness of the fibrous matrix was reduced from $120 \pm 15$ to $95 \pm 10 \mu \mathrm{m}$. The diameters of PHB fibers and their size distribution were studied via electron microscopy on a Hitachi TM-1000 scanning electron microscope (Japan). The statistical analysis of the fiber-diameter distribution was performed via mathematical treatment of images recorded with the scanning electron microscope.

The molecular mobility was estimated via the spin-probe technique on an EPR-V automated EPR spectrometer (Semenov Institute of Chemical Physics, RAS, Moscow). As a probe, the stable nitroxyl radical 2,2,6,6-tetramethylpiperidin-1-oxyl (TEMPO) was used. The radical was incorporated into films from vapor at $60^{\circ} \mathrm{C}$ to a concentration not exceeding $10^{-3} \mathrm{~mol} / \mathrm{L}$. The ESR spectra were recorded in the absence of saturation, a condition that was verified by the dependence of the signal intensity on the microwave field power. The correlation times of probe rotation, $\tau$, were calculated from the ESR spectra according to the following formula [23]:

$$
\tau=6.65 \times 10^{-10} \Delta H^{+}\left(\sqrt{I^{+} / I^{-}}-1\right),
$$

where $\Delta H^{+}$is the width of the low-field component of the spectrum and $I^{+} / I^{-}$is the ratio of intensities of the low- and high-field components. The measurement error for $\tau$ was $\pm 7 \%$.

The ozone oxidation of samples was conducted in an ozone-oxygen mixture with a partial ozone concentration of $5 \times 10^{-4} \mathrm{~mol} / \mathrm{L}$. The DSC measurements were performed on a Netzsch DSC $204 \mathrm{~F} 1$ calorimeter in argon at a heating rate of $10 \mathrm{~K} / \mathrm{min}$. The average measurement error for heat effects was approximately $\pm 3 \%$.

\section{Results and discussion}

During electrospinning, the characteristics of the initial solution have an effect not only on the morphology of the resulting ultrathin fiber but also on such an important parameter as the cross section (Fig. 1). The microscopic images show the change in the fiber diameter distribution and the position of its maximum with a relatively weakly increase in the PHB concentration in the spinning solution from 5 to 7 wt. \%. The requirements on the fiber geometry may vary with the application conditions. The development of sensors (for example, fiberoptic sensors) req-uires, as a rule, a decrease in the fiber diameter to the nano level to improve the sensitivity, whereas, in the case of biomedical fiber materials used, in particular, as matrixes for cell engineering, nano-fibers result in deterioration of cell adhesion and a reduced cellgrowth rate [24]. 


\section{ТЕХНИКО-ТЕХНОЛОГИЧЕСКИЕ ИННОВАЦИИ}

The possibility to control ultrathin fiber geometry through variation in the physicochemical characteristics of a solution has been described in a number of recent works [25]. In our case, a $7 \%$ PHB spinning solution in chloroform was chosen as a basic variant mainly because of the good reproducibility of the physico-chemical characteristics and the geometry of fibers prepared from this solution. As was shown in our previous work, matrixes based on fibers $\sim 1 \mu \mathrm{m}$ in diameter have demonstrated high biocompatibility relative to that of fibers of smaller diameters [24]. On the basis of the above results, further study was performed with matrix fiber systems characterized by a size distribution maximum near $1 \mu \mathrm{m}$.

The results of measurement of segmental mobility were considered along with DSC measurements of the temperature transitions of PHB. With the use of this method, the regions of melting of the crystalline phase in fiber samples were determined.

The melting of PHB films was studied in previous studies [26-28]. The DSC curves for all samples before and after rolling have similar patterns, but their melting maxima fall in different temperature ranges (Fig. 2). The discrepancy in the melting temperatures becomes more pronounced for samples subjected to a heatingcooling cycle (second temperature scan). First, for all samples after the repeated heating, the single melting maxima change to maxima of the bimodal shape at 161.6 and $149.3{ }^{\circ} \mathrm{C}$ for samples before rolling and at 166.5 and $157.5^{\circ} \mathrm{C}$ for the same samples after rolling. Second, the hightemperature melting peaks during the second heating decrease by more than $10^{\circ} \mathrm{C}$, a phenomenon that indicates less than perfect organization of the crystalline phase of samples that is due to their melt cooling to room temperature.

The thermograms of PHB after rolling show higher low and high temperature maxima of melting (see above) with no change in the high crystallinity of samples $(\sim 79 \%)$. The basic conclusions made from the quantitative estimation of thermograms of PHB fibrous matrix melting are as follows. The mechanical treatment via rolling and single heating results in the bimodal separation of the crystalline phase into closer to and further from perfect crystalline regions, a
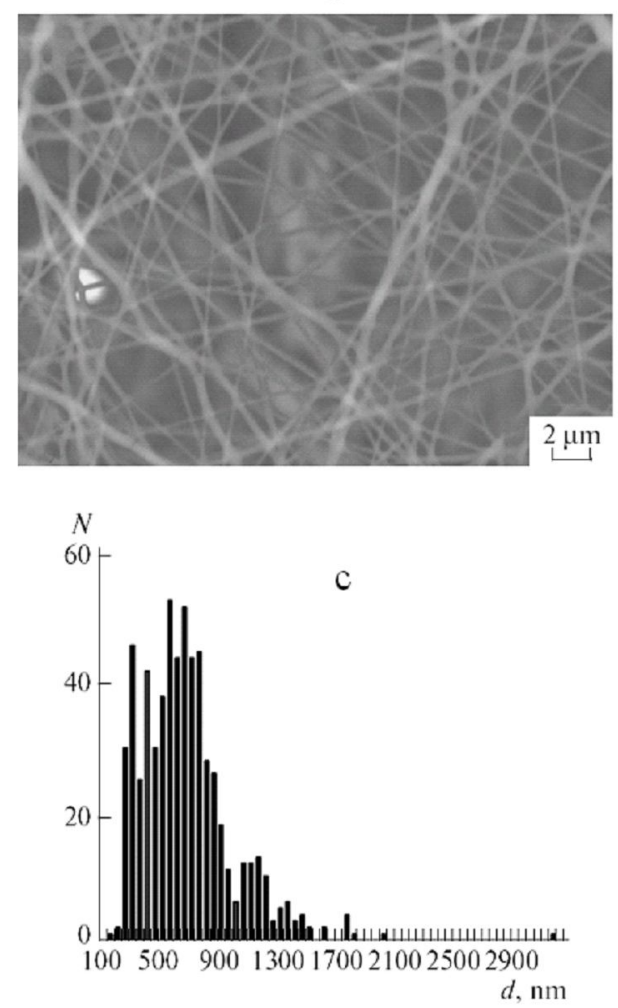

b
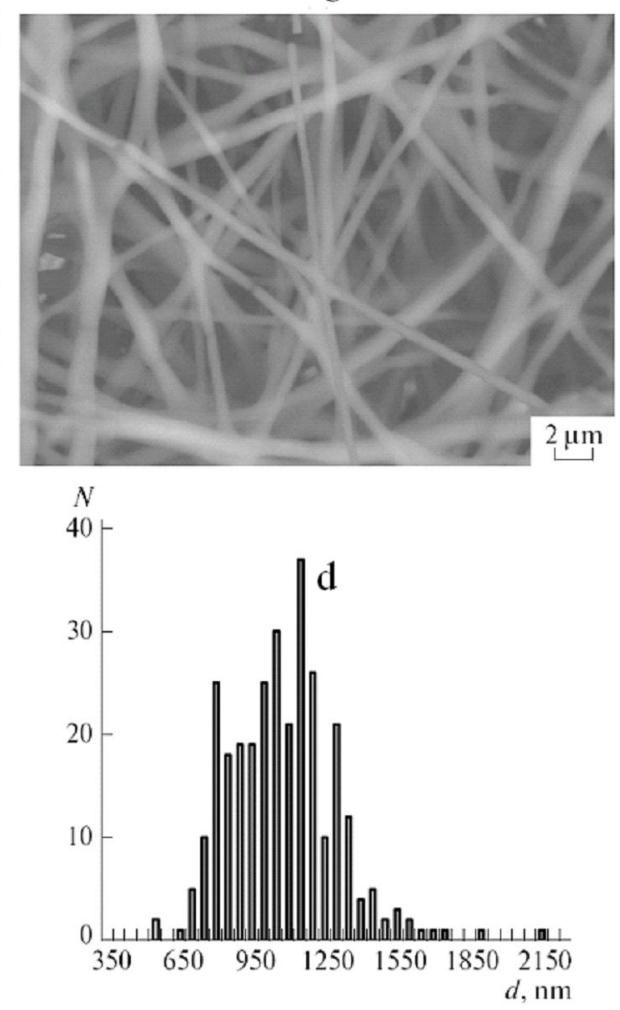

Fig. 1. (a, b) SEM images of PHB fibers prepared via electrospinning of (a) 5 and (b) $7 \%$ polymer solutions; $(c, d)$ the corresponding fiber-diameter distributions 

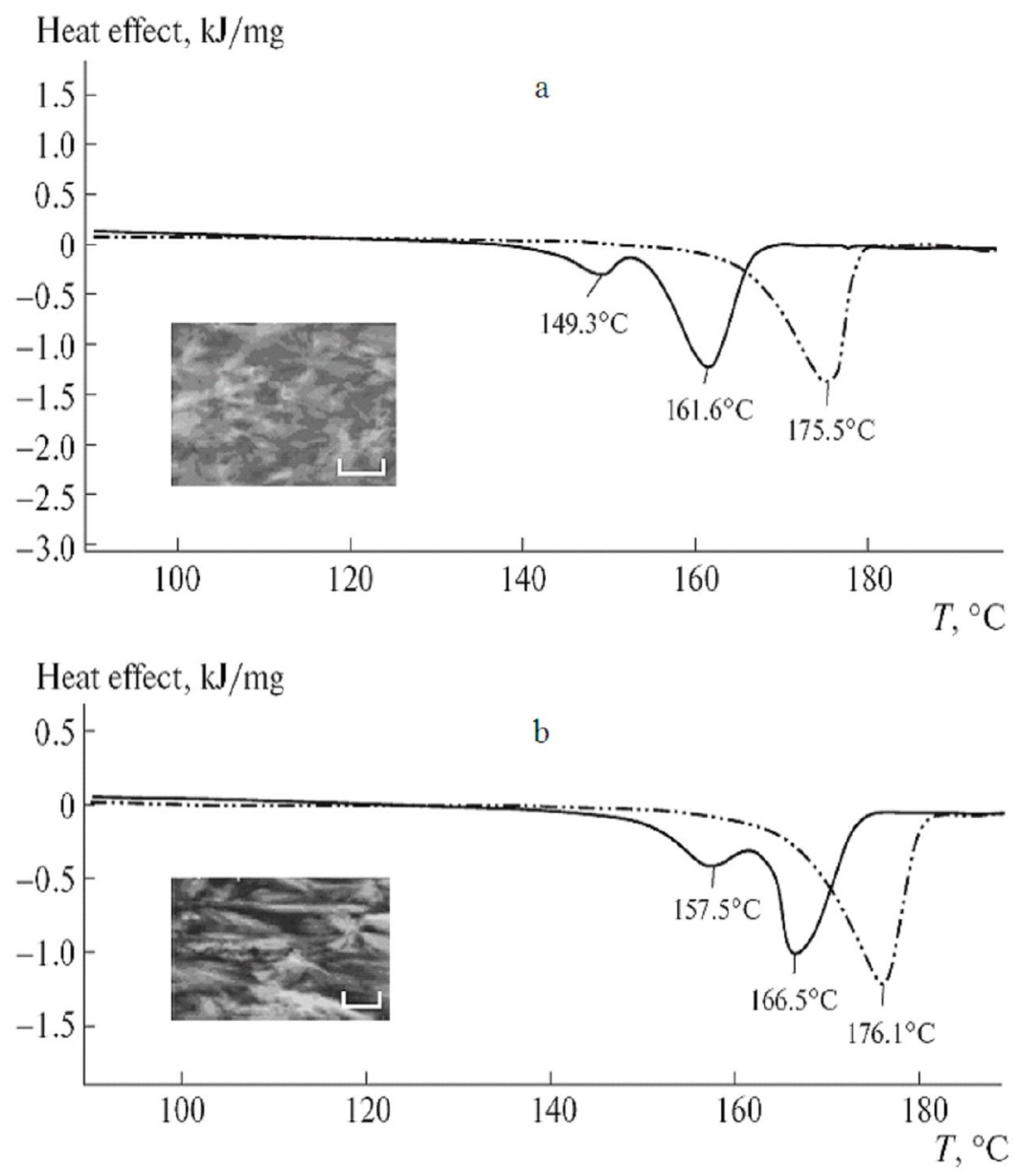

Fig. 2. Thermograms of melting of the fibrous matrix of PHB (a) before and (b) after mechanical treatment via rolling: The single maximum to the right is related to the first temperature scan; the binary maximum corresponds to the second temperature scan. Inserts: SEM images of crystalline regions of PHBs in the form of (a) a fibrous matrix and (b) a fibrous matrix after cold rolling. The markers indicate $0.2 \mu \mathrm{m}$

i. e. regions with different numbers of defects. The same mechanical action favors the improvement of the crystalline structure, a circumstance that is reflected by higher melting maxima on the DSC curves. The presence of two crystalline fractions may lead to the heterogeneity of the amorphous intercrystalline phase of PHB, which is denser and more ordered or less ordered.

The latter conclusion is less evident and requires additional corroboration, which will be attained via microprobe ESR spectroscopy, which makes it possible to estimate both the dynamic characteristics of the motion of PHB segments and the differences in density of its amorphous phase considered as a combination of more ordered and less ordered regions [29].

The ESR spectra of the TEMPO radical in a film and in a matrix formed on the basis of PHB ultrathin fibers is the superposition of two individual spectra of radicals with different correlation times $\tau_{1}$ and $\tau_{2}$ (Fig. 3). Here, $\tau_{1}$ and $\tau_{2}$ reflect the segmental mobilities in amorphous regions with higher density and lower density, respectively. The presence of at least two correlation times in the amorphous regions of $\mathrm{PHB}$ fibrous matrixes is indicative of the heterophasic structure of intercry-stalline polymer regions and is in agreement with the modern model of the bimodal structure of the amorphous phase of partially crystalline polymers, such as PHB, polylactide, and PET [27].

The ESR spectra were quantitatively processed with the use of the equation as well as via calculation of the intensity ratios of low field peaks due to radicals with a retarded motion mode and a more rapid motion mode, respectively (Fig. 3). The distinctions between the two states of the radical in the PHB film are more pronounced than those in the fiber system, as exemplified by the 


\section{ТЕХНИКО-ТЕХНОЛОГИЧЕСКИЕ ИННОВАЦИИ}

comparison of ratios. In the film, this ratio is higher than that in the fiber ( 0.52 and 0.37$)$. Moreover, the effective correlation times corresponding to the rotational mobility of the radical in the fiber before and after rolling $\left(0.92 \times 10^{-9}\right.$ and $1.8 \times 10^{-9} \mathrm{~s}$, respecttively) are significantly lower than the analogous characteristic in the film $\left(4.5 \times 10^{-9} \mathrm{~s}\right)$, an outcome that suggests more rapid rotation of the radical in the amorphous phase of PHB fibers.

In addition to the dynamic measurements, the concentrations of the radical sorbed in identical weighed portions of film, the initial fiber, and the fiber after cold rolling were determined experimentally. The calculations based on the integration of the ESR spectra showed that the above concentrations were as high as $4.6 \times 10^{18} \mathrm{spin} / \mathrm{g}\left(9.5 \times 10^{-4} \mathrm{~mol} / \mathrm{L}\right)$ in the film, $2.9 \times 10^{18} \mathrm{spin} / \mathrm{g}\left(6.0 \times 10^{-4} \mathrm{~mol} / \mathrm{L}\right)$ in the initial film, and $2.610^{18} \mathrm{spin} / \mathrm{g}\left(5.4 \times 10^{-4} \mathrm{~mol} / \mathrm{L}\right)$ in the fiber after rolling. With consideration for the fact that the radical sorption was conducted under identical conditions at a lower PHB crystallinity ( $\sim 9 \%$ \%), these results are indicative of a decrease in the specific volume of the polymer capable of accommodating the radical, i. e. an increase in the fraction of the denser amorphous phase of fibers due to cold rolling. Thus, the comparative analysis of the ESR spectra showed that the pristine samples in the form of a continuous matrix or a matrix formed by fibers substantially differ in the rotational mobility of the radical and the organization of the intercrystalline phase in PHB films and fibers. The above effect supposedly arises as a result of the turning of spherulites and their orientation along the stretching (rolling) direction (micrographs in Fig. 2), a situation that affects the intercrystalline space without significant changes in the polymer crystallinity.

The temperature dependences of the correlation time in conventional semilogarithmic coordinates allowed the determination of the activation energy of the rotational mobility of the radical in the studied polymer samples (Fig. 4,a). The related calculations showed that activation energies in films, fibers, and fibers after rolling are 18,42 , and $55 \mathrm{~kJ} / \mathrm{mol}$, respectively. The successive growth of activation energy after moving from the film to the oriented fiber matrix suggests that there is an increasing energy barrier during radical rotation owing to the hindrance of the segmental mobility in dense regions of the amorphous phase of the polymer in the above-given sequence during consideration of the radical concentration: in the film $<$ in the fiber $<$ in the fiber after rolling.

The temperature dependence of the correlation time for the fiber matrix after rolling demonstrated anomalous behavior (Fig. 4, b) observed in the moderately high temperature range from $72{ }^{\circ} \mathrm{C}$ or lower as a deviation from the semilogarithmic dependence. This phenomenon may be explained by the bimodal distribution of the radical in the partially oriented amorphous phase and by the related difference in the rates of radical rotation. The changing rate of radical rotation results from the redistribution of dense and less dense regions of the amorphous phase of PHB. The observed decrease in the probe mobility is probably related to the increase in the fraction of the dense amorphous phase, a finding
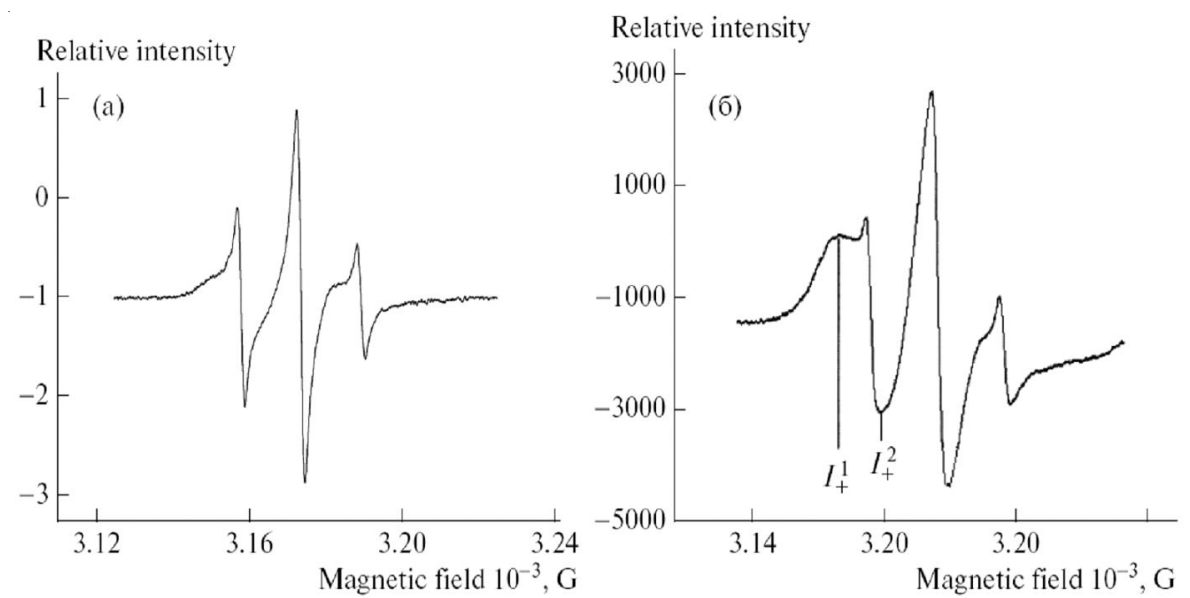

Fig. 3. ESR spectra of TEMPO in (a) the PHB film and (b) the fibrous matrix at $25{ }^{\circ} \mathrm{C}$ that demonstrate the superposition of two simple spectra of radicals with different correlation times (rapid and slow modes) 

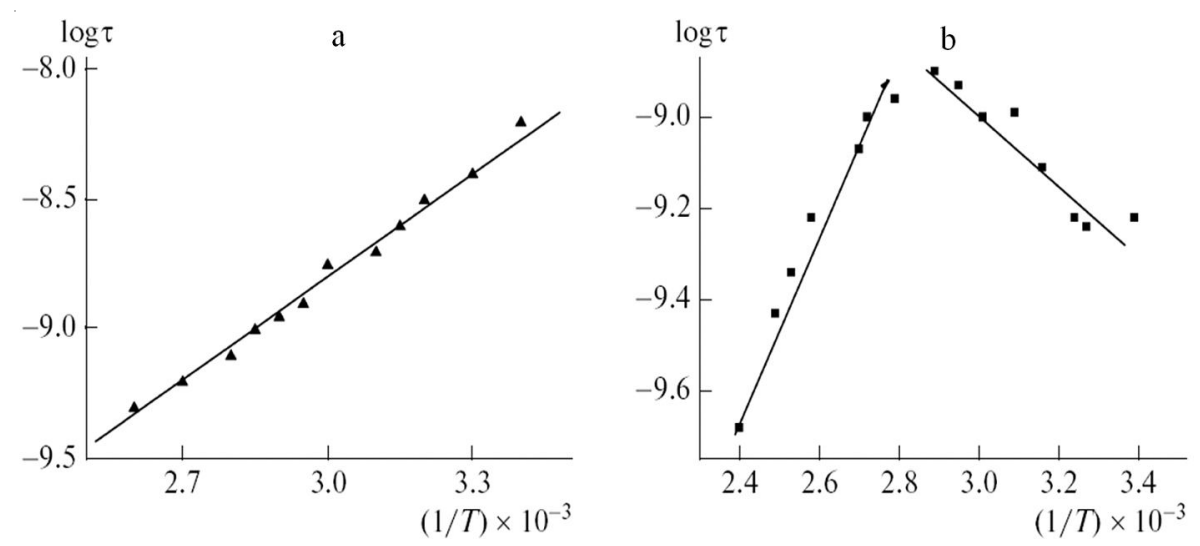

Fig. 4. Dependences of correlation time on inverse temperature for (a) the fibrous matrix and (b) the same matrix after cold rolling

that correlates with the measurements of heat effects via the DSC method [28]: During heating of PHB samples, the segmental mobility and the probability of a denser packing of macromolecules in the intercrystalline space increase simultaneously. At temperatures above room temperature but below $70^{\circ} \mathrm{C}$, the content of the dense amorphous phase increases, resulting in reduced effective mobility of the radical in PHB.

Note that, in a thorough study by M.L. Di Lorenzo, et al. [27], it was shown that during the heating of PHB samples accompanied by cold crystallization (a broad exothermic peak above $60^{\circ} \mathrm{C}$ ), regions of a denser amorphous phase characterized by low mobility and significant segmental orientation are formed. In our case, during dynamic ESR measurements, this transition is observed at $\sim 70^{\circ} \mathrm{C}$ or below (it corresponds to the beginning of the anomalous portion on the curve of inverse temperatures (Fig. 4)), i. e., in the temperature range preceding cold crystallization.

The effect of water, which is known to be a moderate plasticizer of PHB [30], first results in an increase in macromolecular mobility and then favors the formation of more dense regions, where the mobility of the radical decreases. Fig. 5 shows the dependences of effective correlation times on the times of contact of the fibrous matrix with water at $40{ }^{\circ} \mathrm{C}$, i. e. in the physiological temperature range.

As can be seen from Fig. 5, the correlation time of rotational diffusion of the radical (hereinafter it will be called the correlation time for short) increases with the time of contact of the fiber with water, a result that suggests a reduced segmental mobility of PHB, most probably, due to the same process described in the preceding series of temperature-dependence measurements. During the effect of water, the segmental mobility grows, thereby resulting in easier formation of ordered structures, as in the case of the preliminary crystallization of plasticized polymers. Finally, the fraction of the ordered denser amorphous phase of PHB increases. By comparing the correlation times in fibrous matrixes before and after rolling, we can easily see that, as a consequence of the rolling, the correlation times of oriented samples increase; i. e. the segmental mobility decreases (Fig. 5). The fiber orientation in the course of rolling is in fact responsible for the depleted set of extended-chain conformations, a circumstance that results in a drop in the segmental mobility and, hence, increased $\tau$ values for treated fibers.

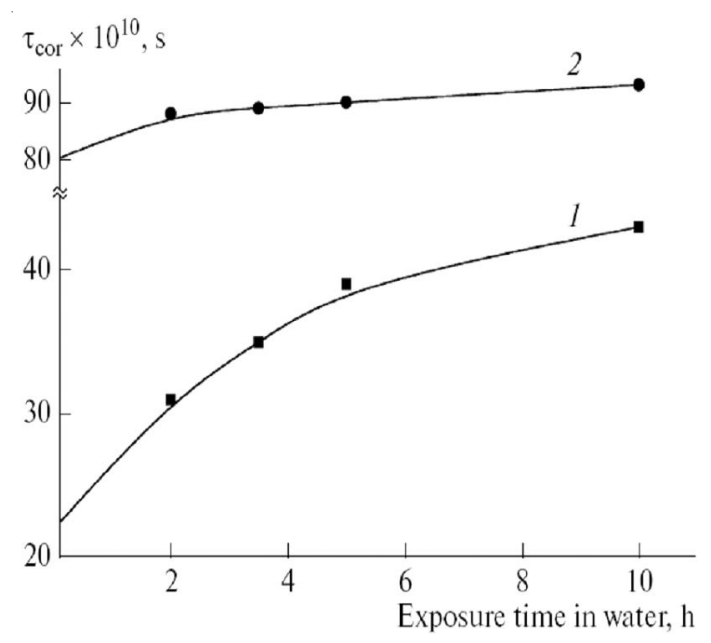

Fig. 5. Correlation time vs. time of contact with the aqueous medium: (1) pristine fibrous matrix and (2) the same matrix after mechanical treatment 
The behavior of the PHB samples in ozone, which is a strong oxidant affectting the structure and mobility of PHB molecules, was estimated via investigation of the rotational dynamics of the TEMPO probe. Fig. 6 shows the dependence of correlation time on the time of ozone oxidation. Within the first hour, a sharp drop of $\tau$ values occurs, and then (up to $4 \mathrm{~h}$ later) the process is strongly retarded and the plot of $\tau$ versus oxidation time flattens out. As the action of ozone continues, the PHB samples demonstrate a further increase in segmental mobility (a decrease in correlation time). Note that the dynamics of the rotation of the radical in pristine fibrous PHB samples and in the same samples after rolling remains the same.

During the action of moisture and temperature, the samples modified via rolling demonstrated lower mobility of the radical at all ozonization times, as previously. On the basis of the preceding measurements of the crystalline structure and probe mobility in ozonized PHB samples [30], it may be proposed that, at the initial stage of oxidation, ozone initiates the partial degradation of macrochains and, consequently, their molecular mobility increases. At this stage, the most accessible and imperfect polymer molecules, which are located in less dense regions of the amorphous phase, participate in the reaction. With their oxidation completed, the process is stabilized, a circumstance that is reflected by the 2 - to 3 -hour long induction period (Fig. 6). Further oxidation with ozone proceeds more intensely and involves not only the "loose" amorphous region of the polymer but also the more ordered dense amorphous zones.

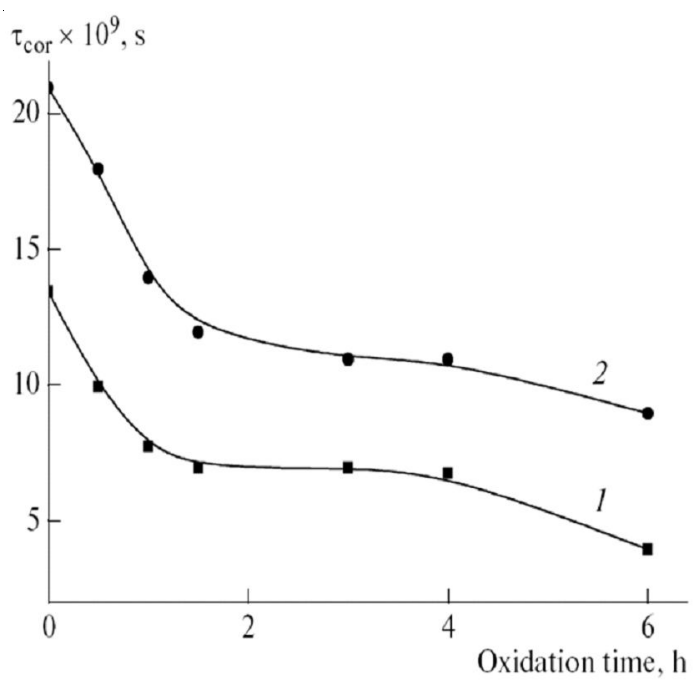

Fig. 6. Correlation time of TEMPO vs. time of ozone oxidation in (1) the pristine fibrous matrix and (2) in the same matrix after cold rolling
Note that, in fibers after rolling, the jumpwise increase of mobility is less pronounced than that of the initial fibers. With consideration for the above results, this effect makes it possible to assume that the rolling leads to the formation of denser amorphous regions in PHB fibers and thereby improves their stability against oxidation by ozone.

Thus, the structural and dynamic analysis combining DSC measurements and molecularmobility determination via the spin-probe method has shown that during the action of an external mechanical field, not only a change in the morphology of PHB and turning of its spherulites occur but also, according to the ESR data, the redistribution of the radical involving well-oriented chains in the amor-phous region of polymer is observed.

According to the DSC data, the changes in the crystalline phase are related to the redistribution of macromolecular segments in the amorphous phase. To allow for molecular mobility, a model of the binary distribution of segments in less and more dense intercrystalline regions responsible for more and less rapid rotation of the TEMPO radical, respectively, was used [30]. The action of temperature and the exposure time in an aqueous medium results in redistribution of the ratio between the "loose" phase and the dense phase of PHB in favor of the dense phase, a circumstance that is reflected in the rotational dynamics of the probe encapsulated in ultrathin PHB fibers. The oxidation of fibrous matrixes of PHB via ozonization occurs in three stages: the reaction of ozone with macromolecules in the "loose" region; a latent period of 2-3 $\mathrm{h}$ without a significant change in the segmental mobility; and the reaction of ozone in denser regions of the polymer amorphous phase, which results in higher rotational mobility of the ESR probe. The comparative measurements of the rotational dynamics of the probe before and after rolling showed that the additional orientation of the PHB spherulites in a mechanical field leads to stabilization of the amorphous regions more resistant to the aggressive effect of ozone.

The proposed approach to the investtigation of ultrathin fibers in the PHB matrix makes it possible to analyze the changes in the segmental mobility of macromolecules at early stages of their interaction with aqueous and oxidative aggressive media. 


\section{ACKNOWLEDGEMENTS}

This work was supported by the Russian Foundation for Basic Research (project no. 14-03-00405-a) and the Program of Basic Research of the Division of Chemistry and Materials Sciences, Russian Academy of Sciences, "Development of Macromolecular Structures of a New Generation" (OKhNM-1-2014).

\section{REFERENCES}

1. Agarwal S., Greiner A., Wendorff J.H. Functional materials by electrospinning of polymers Prog. Polym. Sci., 2013, vol. 38 (6), p. 963. DOI: 10.1016/ j.progpolymsci.2013.02.001.

2. Baji A., Mai Y.W., Wong S.C., Abtahi M., Chen P. Electrospinning of polymer nanofibers: Effects on oriented morphology, structures and tensile properties. Comp. Sci. Technol, vol. 70, iss. 5, May 2010, pp. 703-718. DOI: 10.1016/j.compscitech. 2010.01.010.

3. Banica F.G. Chemical sensors and biosensors: fundamentals and applications. Chichester, Wiley, 2012, vol. 33. 541 p.

4. Bonartsev A.P., Livshits V.A., Makhina T.A., Myshkina V.L., Bonartseva G.A., Iordanskii A.L. Controlled release profiles of dipyridamole from biodegradable microspheres on the base of poly(3hydroxybutyrate). Express Polym. Lett., 2007, vol. 1 (12), pp. 797-803. DOI: 10.3144/expresspolymlett.2007.110.

5. Buchachenko A.L., Vasserman A.M. Stable Radicals. Moscow, Khimiya Publ., 1973.

6. Di Lorenzo M.L. and Righetti M.C. Evolution of crystal and amorphous fractions of poly[(R)-3hydroxybutyrate] upon storage. Journal of Thermal Analysis and Calorimetry, 2013, vol. 112, iss. 3, pp. 1439-1446.

7. Di Lorenzo M.L., Gazzano M., Righetti M.C. The Role of the Rigid Amorphous Fraction on Cold Crystallization of Poly(3-hydroxybutyrate). Macromolecules, 2012, vol.45(14), pp. 5684-5691. DOI: 10.1021/ma3010907.

8. Dvir T., Timko B.P., Ko-hane D.S., Langer R. Nanotechnological strategies for engineering complex tissues. Nature Nanotechnology, 2011, no. 6 (1), pp. 13-22. DOI: 10.1038/nnano.2010.246.

9. Filatov Y., Budyka A., Kirichenko V. Electrospinning of Microand Nanofibers: Fundamentals in Separation and Filtration Processes. New York, Begell House Inc., 2007. 404 p.

10. Filatov Yu.N. Electrospunning of Fibrous Materials (ESF processes). Moscow, Neft i gaz Publ., 1997. (in Russian).

11. Galeski A. Strength and toughness of crystalline polymer systems. Progress in Polymer
Science, 2003, vol. 28, iss. 12, pp. 1643-1699. DOI: 10.1016/j.progpolymsci.2003.09.003.

12. Greiner A., Wendorff J.H. Functional selfassembled nanofibers by electrospinning. Adv. Polym. Sci., 2008, vol. 219, pp. 107-171.

13. Iordanskiy A.L., Kamaev P.P. Segmental mobility in crystalline poly(3-hydroxybutyrate) studied by EPR probe technique. Polym. Sci., Ser. B, 1998, vol. 40 (1-2), p. 8.

14. Iordanskiy A.L., Bonartseva G.A., Pankova Yu.N., Rogovina S.Z., Gumargalieva K.Z., Zaikov G.E., Berlin A.A. Current State-of-the-Art on Novel Materials. New York, Apple Academic Press, 2014, vol. 1, Chap. 12, p. 122.

15. Ivantsova E.L., Kosenko R.Yu., IordanskiyA.L., Rogovina S.Z., Prut E.V., Filatova A.G., Gumargalieva K.Z., Berlin A.A., Novikova S.P. Structure and prolonged transport in a biodegradable poly(R-3-hydroxybutyrate)drug system. Polymer Science Series A, 2012, vol. 54, iss. 2, pp.87-93. DOI: 10.1134/S0965545X12020058.

16. Kamaev P.P., Aliev I.I., Iordanskiy A.L., Wasserman A.M. Molecular dynamics of the spin probes in dry and wet poly(3-hydroxybutyrate) films with different morphology. Polymer, 2001, vol. 42, iss. 2 , pp.515-520. DOI: 10.1016/S0032-3861(00)00339-6.

17. Karpova S.G., Iordanskiy A.L., Chvalun S.N., Shcherbina M.A., Lomakin S.M., Shilkina N.G., Rogovina S.Z., Markin V.S., Popov A.A., Berlin A.A. Probe mobility dynamics, crystal structure, and isotope exchange in PHBV and SPEU blend compositions. Dokl. Phys. Chem., 2002, vol. 446 (2), pp. 176-179. DOI: 10.1134/S0012501612100041.

18. Karpova S.G., Iordanskiy A.L., Popov A.A., Shilkina N.G., Lomakin S.M., Shcherbin M.A., Chvalun S.N., Berlin A.A. Effect of external influences on the structural and dynamic parameters of polyhydroxybutyrate-hydroxyvalerate-based biocomposites. Russian Journal of Physical Chemistry B, 2012, vol. 6, iss. 1, pp. 72-80. DOI: 10.1134/S1990793112010095.

19. Kim I.D. Advances in Electrospun Functional Nanofibers. Macromol. Mater. Eng, 2013, vol. 298, p. 473. DOI: 10.1002/mame.201300055.

20. Kulezneva V.N., ed. Foundations of Plastic Processing Technology. Moscow, Khimiya Publ., 1995. (in Russian).

21. Kulkarni A., Bambole V.A., Mahanwar P.A. Electrospinning of Polymers, Their Modeling and Applications. Polymer-Plastics Technology and Engineering, 2010, vol. 49, iss. 5, pp. 427-441. DOI: 10.1080/03602550903414019.

22. Ma Q., Mao B., Cebe P. Chain confinement in electrospun nanocomposites: using thermal analysis to investigate polymer-filler interactions. Polymer, June 2011, 22, vol. 52, iss. 14, pp. 3190-3200. DOI: 10.1016/j.polymer.2011.05.015. 
23. Pluta M., Bartczak Z., and Galeski A. Changes in the morphology and orientation of bulk spherulitic polypropylene due to plane-strain compression. Polymer, 2000, vol. 41, iss. 6, pp. 2271-2288. DOI: 10.1016/S0032-3861(99)00364-X.

24. Raghavan P., Lim D.H., Ahn J.H., Nah Ch., Sherrington D.C., Ryu H.S., Ahn H.J. Electrospun polymer nanofibers: The booming cutting edge technology. React. Funct. Polym., 2012, 72, pp. 915-930. DOI: 10.1016/ j.reactfunctpolym.2012.08.018.

25. Rutledge G.C., Fridrikh S.V. Formation of fibers by electrospinning. Advanced Drug Delivery Reviews, 2007, vol. 59, iss. 14, pp. 1384-1391. DOI: 10.1016/j.addr.2007.04.020.

26. Sill T. J., von Recum H.A. Applications in drug delivery and tissue engineering. Biomaterials, 2008, vol. 29, iss. 13, pp. 1989-2006.
27. Staroverova O.V., Olkhov A.A., Kuzmicheva G.M., Domoroshchina E.V., Vlasov N.S., Filatov Yu.N. Ultrathin fibers based on biopolymer polyhydroxybu tyrate (PHB) modified with nanoscale modifications of titanium dioxide. Vestn. MITKHT, 2011, vol. 6 (6), pp.120-127.

28. Staroverova O.V., Shushkevich A.M., Kuzmicheva G.M., Olkhov A.A., Voinova V.V., Olkhov A.A., Zharkova I.I., Shaitan K.V., Sklyanchuk E.D., Guryev V.V. Polymeric nanocomposite for protection against UV. Tekhnol. Zhivykh Sist., 2013, vol. 10 (8), p. 74.

29. Ueda H., Tabata Y. Polyhydroxyalkanonate derivatives in current clinical applications and trials. Adv. Drug Delivery Rev., 2003, vol. 55, iss. 4, pp. 501518. DOI: 10.1016/S0169-409X(03)00037-1.

30. Vlasov S.V., Olkhov A.A. Biodegradable materials. Plast. Massy, 1996, no. 6, p. 40. (in Russian]).

\section{УЛЬТРАТОНКИЕ ВОЛОКНА ПОЛИ(З-ГИДРОКСИБУТИРАТА): СТРУКТУРА И ДИНАМИЧЕСКИЕ ОСОБЕННОСТИ}

\section{Светлана Геннадьевна Карпова}

Старший научный сотрудник,

Институт биохимической физики им. Н. М. Эмануэля РАН

ibcp@sky.chph.ras.ru

ул. Косыгина, 4, 119334 г. Москва, Российская Федерация

\section{Алексей Леонидович Иорданский}

Доктор химических наук, профессор,

глава лаборатории явлений распространения в системах полимера,

Институт химической физики им. Н. Н. Семенова РАН

aolkhov72@yandex.ru

ул. Косыгина, 4, 119991 г. Москва, Российская Федерация

\section{Михаил Викторович Мотякин}

Доктор химических наук, профессор,

Институт химической физики им. Н. Н. Семенова РАН

icp@chph.ras.ru

ул. Косыгина, 4, 119991 г. Москва, Российская Федерация

\section{Анатолий Александрович Ольхов}

Кандидат технических наук, адъюнкт-профессор, старший научный сотрудник,

научно-исследовательская лаборатория «Перспективные композиционные материалы и технологии», Российский экономический университет им. Г.В.Плеханова

aolkhov72@yandex.ru

Стремянный переулок, 36, 117997 г. Москва, Российская Федерация

\section{Сергей Модестович Ломакин}

Кандидат химических наук, заведующий лабораторией химической стойкости полимеров, Институт биохимической физики им. Н. М. Эмануэля РАН

ibcp@sky.chph.ras.ru

ул. Косыгина, 4, 119334 г. Москва, Российская Федерация 


\section{Александр Александрович Берлин}

Доктор химических наук, профессор, академик РАН, директор Института химической физики им. Н. Н. Семенова РАН berlin@chph.ras.ru ул. Косыгина, 4, 119991 г. Москва, Российская Федерация

Аннотация. Был проведен структурно-динамический анализ ультратонких волокон поли(3-гидроксибутирата), основанный на измерениях молекулярной подвижности. Сравнены динамические поведения частично прозрачных образцов во время деформации при условиях электровращения и холодного вращения. Сравнительные результаты сложного расследования пленок и ультратонких волокон поли(3-гидроксибутирата) показали, что электромеханическое действие приводит к дополнительной кристаллизации прозрачных областей, сферолитов и чешуек в полимере.

Ключевые слова: поли(3-гидроксибутират), структурно-динамический анализ, пленки, ультратонкие волокна, полимер. 